\title{
The Other Shoe Drops: Commentary on "Does Paranormal Perception Occur in Near-Death Experiences?"
}

\author{
Kimberly Clark Sharp, M.S.W., L.C.S.W. \\ Seattle, WA
}

\begin{abstract}
Keith Augustine raises questions about my report of a case of veridical out-of-body perception during a near-death experience (NDE). His analysis is based not on my original description of the case but rather on a distorted account in a magazine written by two college students who misrepresented the facts and made unwarranted assumptions to support their beliefs.
\end{abstract}

KEY WORDS: near-death experience; veridical out-of-body perception; journalistic ethics.

How interesting to have lived so long that an incident from my life has achieved "urban legend" status. I should be grateful at least that "the shoe on the ledge" story is not on a website devoted to myths and other debunked Internet stories.

The truth is that there was a Maria who observed and reported everything Keith Augustine wrote. I have not previously defended this story against debunkers precisely because it is the truth, and every attempt to discredit the truth has been so full of holes that it has not been worth my time to address it. The difference now is that in the scientific journal of the International Association for Near-Death Studies (IANDS) a skeptical response to the story of the shoe on the ledge has been built on an old article in an obscure publication that was full of inaccuracies, assumptions, and dubious ethical behaviors.

Kimberly Clark Sharp, M.S.W., L.C.S.W., is a retired Clinical Assistant Professor of Social Work at the University of Washington. Reprint requests should be addressed to Ms. Sharp at P.O. Box 84333, Seattle, WA 98124; e-mail: Kimnde@aol.com. 
I provided the whole detailed account of a woman named Maria who observed a number of scenes during her resuscitation at Harborview Medical Center in Seattle in the first chapter of my book, After the Light (Sharp, 1995). The story has not changed an iota since day one, much less been embellished, even though over the course of time my memory has certainly been affected, as evidenced by the fact that I forgot about a Nike logo on the shoe. This lapse in memory was discovered three years ago when I came across a filmed re-enactment of the event using the actual tennis shoe. In fact, I let a news crew from Philadelphia copy the tape, which was subsequently broadcast throughout the Philadelphia area as part of a local news story. Others have claimed that the shoe never existed, so I am grateful that filmed evidence exists. The film shows me as much younger in very dated clothes, thus belying any suggestion that this was a recently filmed piece.

The day that Maria had an out-of-body experience while flatlining is already stupefying without gilding the lily, though that has not stopped some authors or the media from doing so anyway. Rather than recount the whole episode, I will refer readers to the account in After the Light (Sharp, 1995) and will, in this response, address the article upon which Augustine has based his entire debunking case.

Although I had long since forgotten their names, I do remember the time I spent with two young men from a small college in Canada. They introduced themselves to me on the telephone before attending a Seattle IANDS meeting. The boys impressed me as sincere, enthusiastic, and genuinely interested in the subject of near-death experiences (NDEs), especially that of Maria's NDE. They were especially persistent in their desire to visit the facility where Maria had been hospitalized. I complied with their request for a visit, because, after many years as a Clinical Assistant Professor at the University of Washington, I was a knee-jerk supporter of students' curiosities and I wanted to be helpful. They never mentioned investigating Maria's case, writing an article, involving a third author, or planning to submit an article for publication.

I took these two lads to Harborview Medical Center myself. I showed them from outside the building approximately where I had found the shoe because I could no longer remember which exact window it was. Further confusing the issue was the sharp downward slope of the land under the window (which I told the boys had confused me on the day I searched for the shoe, because Floor 1 looked like Floor 2, Floor 2 
looked like Floor 3, and so on), and the fact that the whole side of the building was now under new construction and was surrounded by a hurricane fence that kept us from getting anywhere close to where I had walked in search of the shoe. They pushed me so hard for an exact location that I finally pointed to a window fourth over from the corner. Ironically, this location became my "truth," but it was a window I chose in order to end the boys' discomforting persistence that I zero in on one specific spot.

The two students asked me to take them inside the hospital, but I told them we could not go into any patients' rooms because I was no longer an employee and would have to go through channels in order not to trespass. They stated their understanding and thanked me for taking the time to give them a "tour." That was the end of that, until a couple of years later, when Bruce Greyson sent me an article published in The Skeptical Inquirer debunking my account of finding the tennis shoe (Ebbern, Mulligan, and Beyerstein, 1996). My immediate reaction was emotional pain because I felt betrayed by those two students. But I had never heard of The Skeptical Inquirer and thought the article was unworthy of a response, so I let it go. Over the years, the occasional person has asked me to respond to the article, but most people, including mainstream print and television media, have seemed not to care about it. However, the article's citation in this Journal has finally prompted me to respond to the piece written by the boys, which served as the sole basis of Augustine's analysis of this case.

First, Augustine wrote: "Clark reported, she proceeded to search room-to-room on the floor above Maria's room, pressing her face hard against the windows to see their ledges." I made this statement to avoid the minutiae of describing the configurations of the various window styles I encountered in my search. One side of one section of the hospital had screened windows. Other sections of the building had different window configurations, depending on which addition of the huge complex I was exploring. Nonetheless, in many rooms things were stacked up against the lower part of the windows, and I did, in fact, have to walk up to the glass to look down upon the ledge.

Second, the boys wrote that they were unable to locate Maria, or anyone who knew her personally. In fact, they never inquired about her. I am the one who told them that I thought she was deceased, and I could have introduced them to other hospital staff who had met Maria and heard her story, if they had asked. As it turned out, after all these 
years, I have accidentally run across three former hospital workers who remember "that patient who saw the shoe on the ledge when she died." I mention this because each encounter was unrelated to the others and almost immediately preceded my writing this response. I am calling these reconnections with former colleagues "mighty timely coincidences."

Third, the boys tried to discredit Maria's memories of her out-ofbody experience (OBE), stating that she would have been quite familiar with the equipment monitoring her, and suggesting that her OBE was nothing more than "a visual memory incorporated into the hallucinatory world that is often formed by a sensory-deprived and oxygen-starved brain" (Ebbern, Mulligan, and Beyerstein, 1996, p. 31, cited in Augustine). They also suggested that she could have picked up details about the emergency room entrance from means not related to her OBE. In fact, I am the one who suggested these skeptical responses to the boys, skeptical responses that I described more fully in After the Light (Sharp, 1995). I was doubting Maria's account because I had not dealt with my own NDE, and I fought hard to come to a reasonable conclusion about how Maria could have observed her resuscitation team. One feature the boys cited as conclusive regarding Maria's OBE was that she described all of the paper on the floor. In fact, that was paper flowing out of the electrocardiogram (EKG) machine onto the floor and kicked under the bed. No one ever educates a cardiac patient to that level of detail. There is absolutely no way that she would have known about the paper. It was not taught, it was not discussed, and it is never shown in television and movies depicting cardiac arrest.

Fourth, the boys stated that they could see a running shoe of their own at the place I described from the ground level. Of course they could; they were a half block away. When I looked for the shoe from the ground, I was following a sidewalk that hugged the building, completely unable to see something visible on the ledge a few stories above me. In fact, the reason I went inside to look was because a bird flew onto a ledge above me and I lost sight of it. That was when I realized that I would not be able to find a smallish object outside the building. Because of construction when the boys visited the shoe site, they could not go anywhere near the same sidewalk, even if it had existed at the time, which it did not, having been built over by a new addition. I told the boys this significant detail, but this did not seem to deter them from going to another location and then proudly 
announcing they could see the shoe. It is not surprising that they could see it from their better vantage point. I wish I had thought of looking from a half block away at the time, but I probably would have been mowed down by an ambulance.

Fifth, I am appalled that the boys trespassed in the hospital and actually entered a two-bed patient room and messed around with the window. Despite the fact that they specifically knew they did not have permission and had not even sought permission in the first place, they apparently had no ethical concerns about their behavior. Besides the act of trespassing, the floor they were on houses people just out of the coronary care unit and the intensive care unit, people with infectious diseases, and people who are immune-suppressed. By trespassing in these patients' rooms, they potentially endangered sick people, in addition to violating their privacy. So in other words, the boys asked readers to believe what they wrote in their article despite their having had no problem being dishonest in the first place.

Sixth, they suggested that Maria could have overheard some mention of the shoe, which would be difficult since she spoke very little English, certainly not the level that would have been required to comprehend the details of a shoe's appearance and location in the building.

Seventh, the boys said that they had no difficulty seeing the shoe's allegedly hidden outer side. I did have difficulty. Perhaps the boys somehow managed to open the window and stick their heads out.

Eighth, they wrote that I did not publicly report the details of Maria's NDE until seven years after it occurred. How did they define "public"? Before that time, I had told anyone who would listen about the shoe; it certainly was not a secret. I had included the story at a nurses' conference at another Seattle hospital and had even spoken about it on a live Seattle television show. Obviously I had "gone public."

Ninth, the article stated that no one would have a way of knowing what leading questions Maria may have been asked or what Maria may or may not have "recalled" that did not fit and was dropped from the record. I translate that as calling me a liar. However, I was there; they were not. How convenient for them to be able to reach such easy conclusions without any supporting evidence other than their imaginations.

Lastly, they suggested that I subconsciously embellished the details to bolster the case, but less than two years ago I discovered that I had 
in fact un-embellished the shoe. I came across an old video, mentioned above, of a re-enactment of the shoe story for a television show. The shoe used for the show was the shoe. I was shocked to see a Nike symbol on the ankle. I had not remembered that at all. As I have stated, shortly thereafter, I loaned this tape to a Philadelphia news station, which broadcast for the public to see the so-called "nonexistent" shoe.

In summation, it was not a good idea for Augustine to build a case on one obscure article written by a couple of kids from a small Canadian college without attempting to confirm their report. And now the other shoe has finally dropped.

\section{References}

Ebbern, H., Mulligan, S., and Beyerstein, B. (1996). Maria's near-death experience: Waiting for the other shoe to drop. Skeptical Inquirer, 20, 27-33.

Sharp, K. C. (1995), After the light: What I discovered on the other side of life that can change your world. New York, NY: William Morrow. 